\title{
Synthesis of $\mathrm{C}-\mathrm{C}$ bonded dimeric steroids by olefin metathesis
}

\author{
Valeria C. Edelsztein, Pablo H. Di Chenna, Gerardo Burton* \\ Departamento de Química Orgánica and UMYMFOR (CONICET-FCEN), Facultad de Ciencias Exactas y Naturales, Universidad de Buenos Aires, \\ Ciudad Universitaria, Pabellón 2, C1428EGA Buenos Aires, Argentina
}

\section{A R T I C L E I N F O}

\section{Article history:}

Received 15 January 2009

Received in revised form 24 February 2009

Accepted 2 March 2009

Available online 6 March 2009

\section{Keywords:}

Dimerization

Metathesis

Dimeric steroids

Microwave

\begin{abstract}
A B S T R A C T
Five new $\mathrm{C}-\mathrm{C}$ bonded steroidal homodimers derived from deoxycholic acid, pregnenolone, and progesterone were synthesized by an olefin metathesis reaction assisted by microwave heating. Microwave improved the yield and accelerated the reaction allowing the use of less catalyst with good results $(2.5 \mathrm{~mol} \%)$. Due to the bulky nature of the steroidal skeleton the more favorable $E$-dimers were formed as the sole or major products depending on the linker length.
\end{abstract}

(c) 2009 Elsevier Ltd. All rights reserved.

\section{Introduction}

Synthesis of symmetric molecules derived from joining two identical moieties has gained importance in recent years. These molecules may act as ligands for proteins and as such, activate cellular processes, ${ }^{1,2}$ or increase the affinity of ligands to their binding sites by providing an extra anchoring to the active site of certain domains. ${ }^{3}$ In particular dimeric steroids represent a class of compounds that have attracted attention for their rigid and inherently asymmetric architecture. ${ }^{4}$ Many dimeric steroids exhibit miscellar, detergent, and liquid crystal behavior. ${ }^{5}$ Also, some dimeric steroids are pharmaceutically important exhibiting various biological activities as cytotoxicity and anticancer potential, ${ }^{6}$ antimalarial, ${ }^{7}$ serum cholesterol lowering effect, ${ }^{8}$ and insect molting alteration. ${ }^{9}$ They have been also used as molecular umbrellas, ${ }^{10}$ building blocks for artificial receptors, ${ }^{11}$ and catalysts for some organic reactions. ${ }^{12}$ The first reports of dimeric derivatives with various inter-steroid linkages resulted from by-product formation, and only in recent years preparation of these compounds has been sought.

Dimeric steroids may be linear or cyclic and may be connected via rings in the steroid nucleus (A-A, B-B, etc.) or through the side chains, the latter being commonly used to form bile acids dimers. The individual moieties may be linked by direct connection or through spacer groups. ${ }^{4}$ In most examples found in the literature,

\footnotetext{
* Corresponding author. Tel./fax: +54 1145763385.

E-mail address: burton@qo.fcen.uba.ar (G. Burton).
}

the connection between the units involves a labile bond such as an ether, amide, amine, hydrazone or ester moiety. Carbon-carbon bonded dimeric steroids should be more stable to biological or harsh chemical media, however they are less common and only a few examples are found in the literature, most of them involving a direct connection between rings. ${ }^{13,14}$ To the best of our knowledge the only report of dimeric steroids linked through carbon-carbon spacers is that by Morzycki et al., ${ }^{15}$ who synthesized a series of dimeric pregnane steroids linked via C-20 with long chain hydrocarbon spacers. The $\mathrm{C}-\mathrm{C}$ dimerization step was performed by a Wurtz reaction and Wicha-Bal alkylation-reduction procedure with very low yields.

During our work directed toward the preparation of structurally diverse analogues of bioactive steroids, capable of invoking a broad spectrum of biological activities, ${ }^{16,17}$ we devised a simple route to prepare $\mathrm{C}-\mathrm{C}$ linked dimeric steroids by means of a metathesis coupling reaction process. Despite being a very mild reaction that tolerates the presence of a wide variety of functional groups, ${ }^{18}$ its use in steroid chemistry is limited. Poirier et al. ${ }^{19}$ prepared some hybrid inhibitors of type $117 \beta$-hydroxysteroid dehydrogenase of estradiol and an adenosine mimic through a step that involves a cross-metathesis reaction with a linear terminal olefin that elongates the side chain at $\mathrm{C}-16$ with moderate but not optimized yield. The recent synthesis of $6 E$-hydroxyiminosteroid dimers, bonded through a linker with an ether functionality at $\mathrm{C}-3$, is the only example of steroid homodimerization by metathesis. ${ }^{20}$ As the steric and spatial orientation requirements of the catalysts for metathesis are critical, predicting the feasibility of such reaction on the proximity of the rigid and highly asymmetric bulky steroidal 
skeleton is not obvious, even using the most reactive terminal olefins. ${ }^{21}$ We report here the synthesis of dimers at C-20 (ring D), C19 and C-6 (ring B) of the steroid skeleton via an olefin metathesis coupling process using Grubbs catalyst (2nd generation) on terminal olefins, with hydrocarbon linkers of different lengths. The effect of microwave (MW) irradiation on the reaction is also presented.

\section{Results and discussion}

\subsection{Homodimerization at the side chain through C-20}

Several bile acid related dimers have been synthesized by connecting the C-20 side chains through a spacer group using ester or amide moieties. The unique characteristics of these steroidal acids in relation to their chiral, rigid, and curved framework, as well as their chemically diverse hydroxyl groups have made them important in tailoring supramolecular hosts. With this in mind we started our work studying the dimerization metathesis reaction at that position. We first prepared 20-methylidene pregnanolone 1 from pregnanolone acetate by a salt-free Wittig reaction (Scheme 1 ). Compound 1, a sterically hindered 1,1-disubstituted olefin, did not dimerize in the presence of Grubbs catalysts (1st and 2nd generation) even under MW heating conditions that have proved to effectively accelerate cross-metathesis reaction between deactivated and terminal olefins. ${ }^{22}$

The homodimerization reaction at the $\mathrm{C}-20$ side chain was then attempted on steroid 3, a terminal olefin with a longer chain easily prepared from deoxycholic acid diacetate $\mathbf{2}$ (Scheme 1 ). The degradation of the side chain of $\mathbf{2}$ was achieved by an oxidative decarboxylation using the methodology developed by Suarez et al. ${ }^{23}$ as an alternative to the classical method with $\mathrm{Pb}(\mathrm{AcO})_{4}$ applied to bile acids. ${ }^{24}$ The homodimerization of $\mathbf{3}$ with 2 nd generation Grubbs catalyst in dichloromethane under conventional heating conditions gave a single product but did not proceed to completion (Table 1, entries 1-3). The product was characterized as the symmetric E-dimer 4, the dimeric nature of the product was confirmed by electrospray (ESI) exact mass spectrometry with a pseudomolecular ion $(\mathrm{M}+\mathrm{Na})^{+}$at 855.5729 corresponding to the molecular formula $\mathrm{C}_{52} \mathrm{H}_{80} \mathrm{O}_{8} \mathrm{Na}$. The ${ }^{13} \mathrm{C}$ NMR spectrum showed 26 signals with a single olefinic carbon resonance at $134.2 \mathrm{ppm}$ in accordance with a symmetric dimeric structure. The ${ }^{1} \mathrm{H}$ NMR spectrum was also consistent with a symmetric dimer and showed the H-22 olefin multiplet at $5.11 \mathrm{ppm}$. Analysis of ${ }^{1} \mathrm{H}$ NMR data for compound 4 was in agreement with the expected $E$ double bond geometry (see
Table 1

Dimerization reaction of steroid $\mathbf{3}$ with Grubbs 2 nd generation catalyst ${ }^{\mathrm{a}}$

\begin{tabular}{llllll}
\hline Entry & Heating & $\begin{array}{l}\text { Catalyst } \\
(\mathrm{mol} \%)\end{array}$ & $\begin{array}{l}\text { Temp } \\
\left({ }^{\circ} \mathrm{C}\right)\end{array}$ & $\begin{array}{l}\text { Time } \\
(\mathrm{h})\end{array}$ & $\begin{array}{l}\text { Yield }^{\mathrm{c}} \\
(\%)\end{array}$ \\
\hline 1 & Conventional & 20 & 40 & 6.5 & 52 \\
2 & Conventional $^{\text {Conventional }}$ & 10 & 40 & 6 & 20 \\
3 & 5 & 25 & 24 & 7 \\
4 & Microwave $^{\mathrm{b}}$ & 10 & 100 & 1.7 & 97 \\
5 & Microwave $^{\mathrm{b}}$ & 5 & 100 & 1.7 & 78 \\
6 & Microwave $^{\mathrm{b}}$ & 2.5 & 100 & 2 & 71 \\
\hline
\end{tabular}

${ }^{\text {a }}$ Reactions were carried out in $0.3 \mathrm{M}$ solutions of $\mathbf{3}$ in dichloromethane.

b Performed in a CEM Discover reactor at $300 \mathrm{~W}$, closed vessel method.

c Yields calculated over isolated product after column chromatography.

below for double bond geometry analysis). Formation of the sterically less favored $Z$-isomer was not observed.

When dimerization of $\mathbf{3}$ was carried out under microwave heating conditions, an important increase in the reaction rate was observed. Using $10 \mathrm{~mol} \%$ 2nd generation catalyst, dimer 4 was obtained in $97 \%$ yield (Table 1, entry 4 ). In addition to the increased yield and reaction rate the MW reaction could be carried out with a significantly lower catalyst load (5-2.5 mol\%), still with good yields (Table 1, entries 5 and 6 ). Grubbs 1 st generation catalyst was unable to dimerize 3, even under MW conditions; in this case, the unreacted starting material was recovered intact after chromatography.

Using the optimized conditions found for $\mathbf{3}$, the microwave assisted dimerization reaction was then performed at C-20 with two spacer groups of different length and a different functionalization of the steroid nucleus. The terminal olefins were prepared from commercial deoxycholic acid and 3-oxo-4-pregnen-20 $\beta$ carboxyaldehyde (8) (Scheme 2). Deoxycholic acid methyl ester (5) was reduced with $\mathrm{LiAlH}_{4}$ to the $3 \alpha, 12 \alpha, 24$-cholanetriol that was oxidized with PCC to give diketoaldehyde 6. A regioselective Wittig reaction with salt-free methylidenetriphenylphosphorane was a direct way to selectively olefinate the aldehyde $\mathbf{6}$ to the terminal olefin 7. The salt-free ylide was prepared from the corresponding phosphonium salt by a methodology previously developed by our group using sodium amide, ultrasound, and a non-polar solvent with very good results. ${ }^{26}$ Monomer $\mathbf{9}$, with an $\alpha, \beta$-unsaturated carbonyl system on ring $A$, was prepared from commercial 3-oxo-4-pregnen-20 $\beta$-carboxyaldehyde using the same Wittig reaction conditions mentioned above with excellent yield (Scheme 2).

Dimerization of compounds $\mathbf{7}$ and $\mathbf{9}$ was carried out under MW irradiation with $2.5 \mathrm{~mol} \%$ of Grubbs 2nd generation catalyst<smiles>C=C(C)[C@H]1CCC2C3CC[C@H]4C[C@H](OC(C)=O)CC[C@]4(C)[C@H]3CCC21C</smiles>

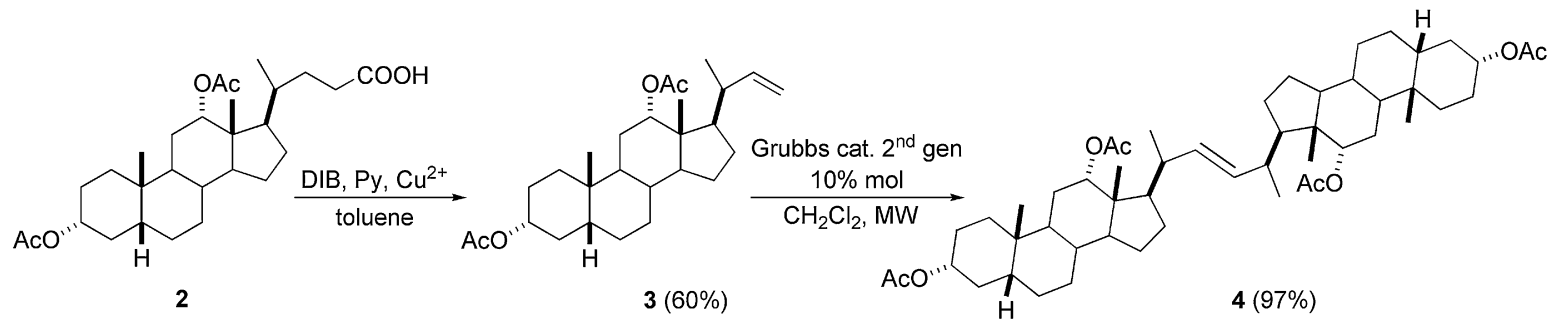

Scheme 1. 


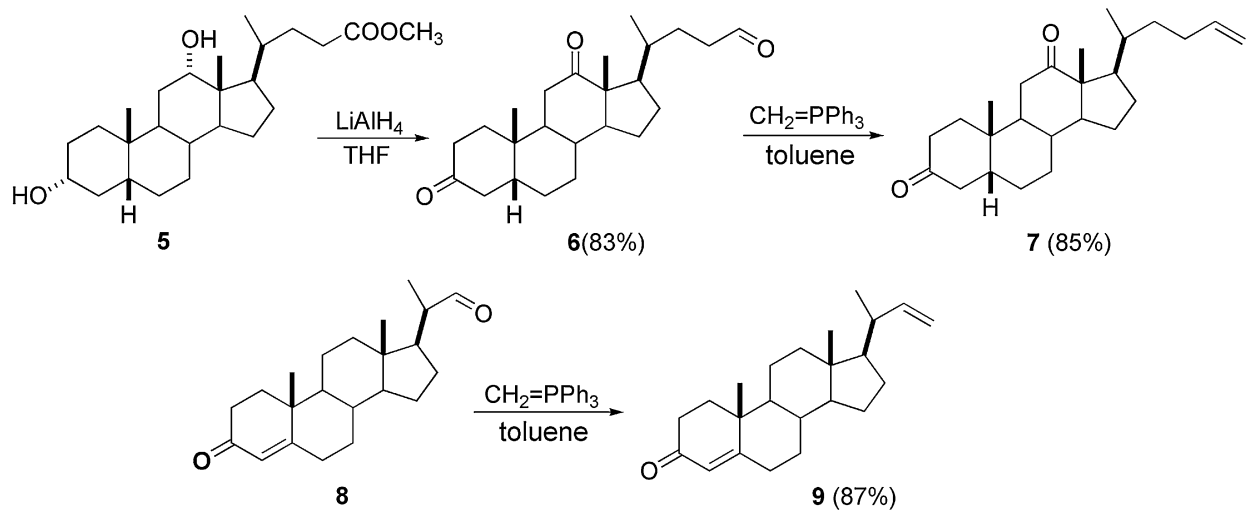

Scheme 2 .

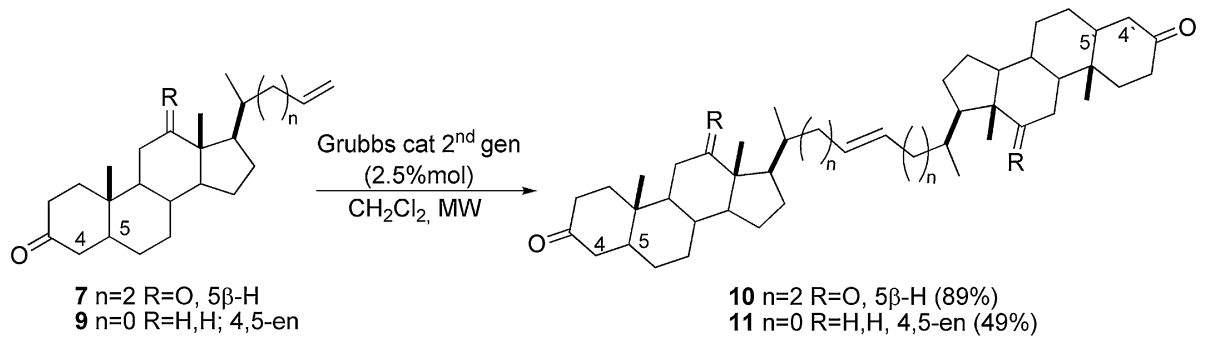

Scheme 3.

(Scheme 3). Steroid 9 gave one dimeric product in $49 \%$ yield; only $10 \%$ of unreacted material was recovered indicating some decomposition of the product and/or starting material under the reaction conditions. Spectroscopic data of $\mathbf{1 1}$ was consistent with the symmetric E-dimer structure as described previously for dimer 4 . In the case of monomer $\mathbf{7}$ with the longer spacer group, dimerization proceeded with very good yield to give a mixture of $E / Z$ isomers (9:1 ratio) as observed by ${ }^{1} \mathrm{H}$ NMR. The small amount of the less favored $Z$-isomer (not observed with compounds 4 and 11) probably arises due to reduced steric hindrance from the steroid nucleus, which is further away from the double bond. As with compound 3, the dimerization of $\mathbf{7}$ and $\mathbf{9}$ did not proceed with 1 st generation Grubbs catalyst in dichloromethane, even under MW heating.

\subsection{Homodimerization at ring B through C-6}

Functionalization of the pregnane skeleton at C-6 starting from steroid 12 is shown in Scheme 4; compound 12 can be easily prepared from pregnenolone acetate. ${ }^{27}$ In order to avoid any interference in the metathesis reaction the $\mathrm{C}-2$ double bond was hydrogenated in the presence of $10 \% \mathrm{Pd} / \mathrm{C}$ to give 6-ketosteroid 13. Addition of allylmagnesium chloride to the 6-ketone in $\mathbf{1 3}$ gave a mixture of $6 \alpha$ and $6 \beta$ allyl steroids (14 and 15) that could not be separated. As expected the major product was the $6 \alpha$-allyl steroid generated by attack to the less hindered alpha face; deacetylation at C-20 was also observed. The mixture of 6-allyl steroids was oxidized with PCC to give after column chromatography the corresponding 20-ketones 16 (72\%) and 17 (9\%). Steroid 13 was also<smiles>CC(=O)OC(C)C1CCC2C3CC(=O)C4CC=CCC4(C)C3CCC12C</smiles>

12<smiles>C=CCC1CCC2C3CC(=O)C4CCCCC4(C)C3CCC12C</smiles><smiles></smiles><smiles>C=C1CC2C(CCC3(C)C(C(C)OC(C)=O)CCC23)C2(C)CCCCC12</smiles>

$18(71 \%)$<smiles>C=CC[C@]1(O)CC2C3CCC(C(C)O)C3(C)CCC2C2(C)CCCCC21</smiles>

14

(84\%, 8:2 ratio)<smiles>CC(O)C1CCC2C3C[C@](O)(CC=C[As])C4CCCCC4(C)C3CCC12C</smiles>

$\mathrm{PCC}, \mathrm{BaCO}_{3}$ mol. sieves $4 \AA$ $\mathrm{CH}_{2} \mathrm{Cl}_{2}$<smiles>C=CC[C@]1(O)C[C@H]2C3CCC(C(C)=O)C3(C)CCC2C2(C)CCCCC21</smiles>

$16(72 \%)$<smiles>CC=CC[C@H]1CC2C(CC[C@]3(C)C(C(C)=O)CCC23)C2(C)CCCCC2[C@@H]1O</smiles> 
converted to olefin 18 via a Wittig reaction with methylidenetriphenylphosphorane. The three olefins were then submitted to MW mediated metathesis reaction with 2nd generation Grubbs catalyst. Compound 17, with the allyl group oriented in an axial position did not dimerize; the same happened when reaction was attempted with the 1,1-disubstituted alkene 18. On the other hand, steroid 16 reacted to give the $E$-dimer 19 as the major product, with a $5 \%$ of the $Z$-isomer detected by NMR (Scheme 5 ). This mixture could not be separated by chromatography, and compound 19 was purified by recrystallization from 2-propanol. The dimeric nature of 19 was confirmed by exact mass spectrometry (ESI) with a pseudomolecular ion $(\mathrm{M}+\mathrm{Na})^{+}$at 711.5323 corresponding to the molecular formula $\mathrm{C}_{46} \mathrm{H}_{72} \mathrm{O}_{4} \mathrm{Na}$. The ${ }^{13} \mathrm{C}$ NMR spectrum showed 23 signals with a single olefinic carbon resonance at $129.51 \mathrm{ppm}$ that showed correlation in the HSQC spectrum with the olefinic multiplet at $5.35 \mathrm{ppm}$ in accordance with a symmetric dimeric structure. Complete analysis of the ${ }^{1} \mathrm{H}$ NMR spectrum $(500 \mathrm{MHz})$ together with 2D spectra (HSQC, HMBC, and COSY) was consistent with a symmetric dimer. The $Z$-isomer could not be separated and was analyzed in the NMR spectra of the mixture, showing also 23 carbon resonances with only one olefinic carbon at $127.38 \mathrm{ppm}$ that correlated with a proton at $5.51 \mathrm{ppm}$ (HSQC). When the mixture of olefins 16 and 17 was submitted to MW metathesis reaction conditions, monomer 16 homodimerized to give 19 while monomer 17 was recovered unreacted after chromatography proving that even the cross-metathesis between the $\alpha$ and $\beta$ allylic groups is not possible under the conditions used.

\subsection{Homodimerization through C-19}

Dimerization at C-19 was particularly interesting, since the angular methyl group has an axial orientation on the $\beta$ face of the steroid. A dimeric steroid connected through C-19 has the

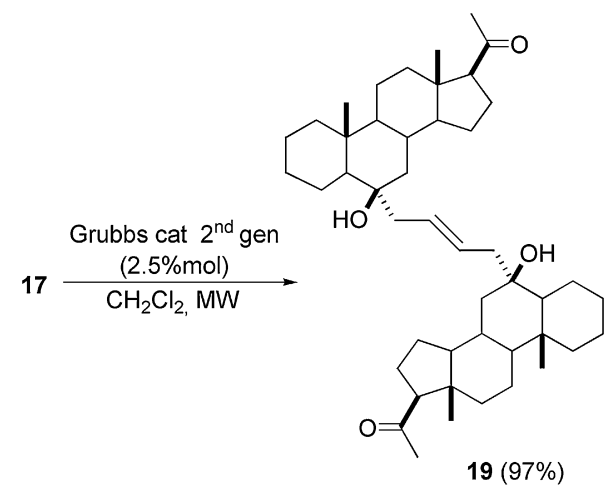

Scheme 5. possibility to oppose both $\beta$ faces that, added to the rigidity of the steroid framework may give rise to a cavity, either hydrophobic or hydrophilic depending on the functionalities present on the steroid nucleus. There is only one example of a C-19 dimeric steroid reported in the literature, this was detected as a by-product in the reaction mixture of a Simmons-Smith methylenation and was connected through a linker containing two ether moieties. ${ }^{25}$

To apply the metathesis reaction to the synthesis of C-19 linked homodimers, we first prepared the C-19 aldehyde steroid 20 and its homologue 22 with one extra methylene group using a methodology previously developed by our group (Scheme 6 ). ${ }^{26}$ The aldehydes were converted to the corresponding terminal olefins 21 and $\mathbf{2 3}$ by a salt free Wittig reaction; the olefins were fully characterized by NMR, mass spectrometry, and elemental analysis. Both monomeric olefins were subjected to metathesis under the microwave conditions previously described for preparation of the other dimers. While olefin $\mathbf{2 1}$ did not dimerize (the starting material was quantitatively recovered after chromatography) its analogue $\mathbf{2 3}$, with a longer chain, and thus less hindered olefin, gave the $E$-dimer 24 in $64 \%$ yield. Only $13 \%$ of unreacted monomer was recovered after chromatography, accounting for some side reactions probably due to the presence of the $\mathrm{C}-5$ double bond. Spectroscopic data was in agreement with the dimeric nature of the product. The ${ }^{13} \mathrm{C}$ NMR spectra of 24 showed the presence of 26 carbon atoms consistent with a symmetric structure with only three olefinic carbon resonances at 124.4 (C-6), 137.1 (C-5), and 129.2 (C-22). The latter carbon showed a 1-bond correlation (HSQC) with the hydrogen at $5.42 \mathrm{ppm}(\mathrm{H}-22)$ and a long-range correlation (HMBC) with both $\mathrm{H}$ 19 at 2.45 and $2.03 \mathrm{ppm}$. The $E$ geometry of the double bond of all dimers was confirmed by a computational and matching procedure of the ${ }^{1} \mathrm{H}$ NMR resonance as described in the following section.

\section{4. ${ }^{1}$ H NMR analysis of the symmetric double bond geometry}

Geometry assignment of the symmetric double bond present on the dimers was not straightforward. Even though we expected the formation of the less hindered E-isomer as the only or major product, chemical equivalence of the olefinic protons due to the symmetric structures precluded using their mutual coupling constant to establish the double bond stereochemistry. However magnetic non-equivalence due to the vicinal hydrogens results in a strongly coupled proton system with irregular splitting and intensity ratios ( $\mathrm{XAA}^{\prime} \mathrm{X}^{\prime}$ or $\mathrm{X}_{2} \mathrm{AA}^{\prime} \mathrm{X}_{2}$ patterns) that contains information on the olefinic protons coupling constant. We solved the problem by using a computational and matching procedure. The simulations $\left({ }^{1} \mathrm{H} \mathrm{NMR}, 500 \mathrm{MHz}\right)$ were carried out using the experimental chemical shift data taken from the spectra of the dimers; the coupling constants were estimated from the spectra of the corresponding monomers $\left({ }^{3} J_{Z} \approx 10-13 \mathrm{~Hz}\right.$ and $\left.{ }^{3} J_{E} \approx 16-17 \mathrm{~Hz}\right)$.<smiles>CC(=O)OC(C)C1CCC2C3CC=C4CC(OC(C)=O)C(OC(C)=O)CCC4(CC=O)C3CCC12C</smiles>

Scheme 6. 
(a)
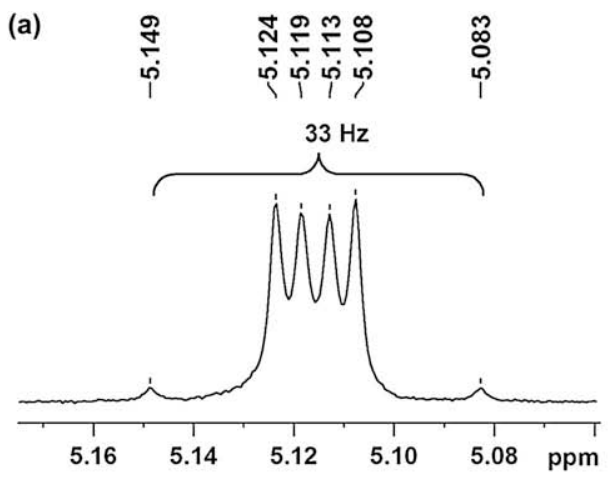

(b)

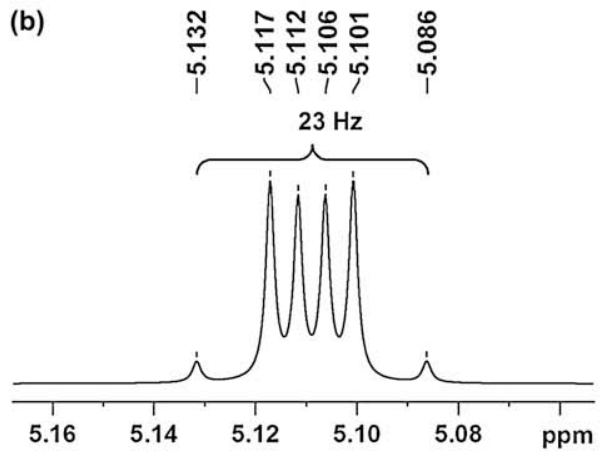

(c)

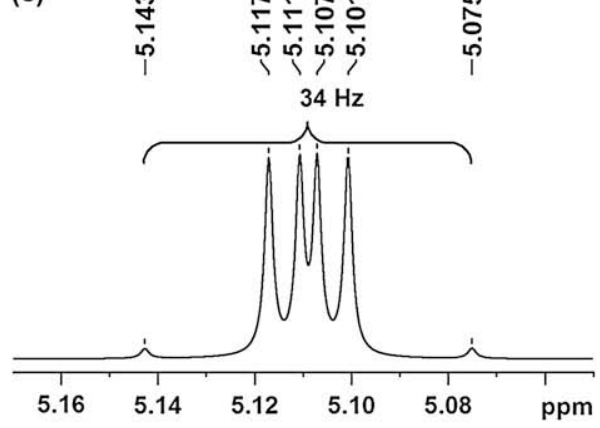

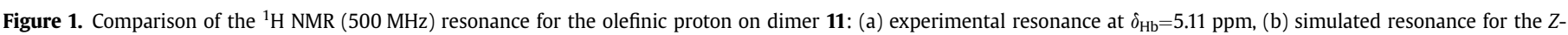

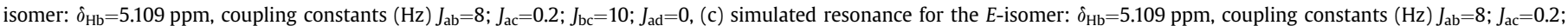
$J_{\mathrm{bc}}=16 ; J_{\mathrm{ad}}=0$ (simulations with NMR-SIM TOPSPIN 2.1).

Using these values we simulated the systems as exemplified for dimer 11 (Fig. 1). Simulation of the $E$ alkene dimers gave a resonance for the olefinic proton that perfectly matches the experimental result with a splitting between the outer lines of $34-35 \mathrm{~Hz}$ (ca. $2 \times J_{E}$ ). For the $Z$ isomers the splitting was $22-23 \mathrm{~Hz}$ (ca. $2 \times J_{Z}$ ) (see Supplementary data).

\section{Conclusions}

Microwave assisted metathesis reaction of terminal steroidal olefins has proven to be a useful methodology for the preparation of homodimeric steroids. In all cases microwave irradiation accelerated the reaction rate and also improved the yield compared with conventional heating allowing to lower the load of catalyst to $2.5 \mathrm{~mol} \%$ with acceptable yields. Overall five dimeric steroids linked through C-6, C-19, and C-20 were obtained and fully characterized, the homodimers had the $E$ geometry although for compounds 10 and 19 a small amount (less than 10\%) of $Z$-isomer was detected by NMR.

\section{Experimental}

\subsection{General}

Melting points of crystalline solids were measured on a Fisher Johns apparatus and are uncorrected. IR spectra were recorded in thin films using $\mathrm{KBr}$ disks on a Nicolet Magna IR 550 FT-IR spectrometer. ${ }^{1} \mathrm{H}$ and ${ }^{13} \mathrm{C}$ NMR spectra were measured on a Bruker Avance II 500 (500.13 and $125.72 \mathrm{MHz}$ ) NMR spectrometer in deuteriochloroform using TMS as internal standard. The electron impact mass spectra were measured on a Shimadzu QP-5000 mass spectrometer at $70 \mathrm{eV}$ or on a VG-Trio 2 at $20 \mathrm{eV}$, by direct inlet. Exact mass spectra (ESI) were measured on an Agilent LCTOF, high resolution TOF analyzer with APCI/ESI ionization. Elemental analysis was performed on an EAI Exeter Analytical, Inc. CE-440 apparatus. Microwave assisted reactions were carried out in a CEM Discover reactor. Analytical thin layer chromatography (TLC) was performed on pre-coated silica plates (Merck $\mathrm{F}_{254}, 0.2 \mathrm{~mm}$ thickness); compounds were visualized by staining with cerium molybdate (Hannessian's stain). Flash column chromatography was performed on silica gel Merck $9385(0.0040-0.0063 \mathrm{~mm})$ or Florisil. All solvents used were reagent grade. Solvents were evaporated at $45^{\circ} \mathrm{C}$ under vacuum in a rotary evaporator. The homogeneity of all compounds was confirmed by TLC. Products obtained as solids or syrups were dried under high vacuum. $3 \alpha, 12 \alpha$-Diacetoxy-5 $\beta$ cholan-24-oic acid (2) was prepared from commercial deoxycholic acid following the procedure described in the literature. ${ }^{24} 3 \alpha, 12 \alpha-$ Dihydroxy-5 $\beta$-cholanic acid methyl ester (5) was prepared by esterification of deoxycholic acid with methanol/HCl. ${ }^{25} 3 \beta, 20 \beta-$ Diacetyloxy-5-pregnen-19-al (20) and 3 $\beta, 20 \beta$-diacetyloxy-5-pregnen-19-carboxyaldehyde (22) were obtained as described previously. ${ }^{26}$

\subsection{Preparation of 'salt-free' methylidenetriphenyl- phosphorane}

To $420 \mathrm{mg}$ ( $10.7 \mathrm{mmol}$ ) of powdered sodium amide in toluene $(18.5 \mathrm{~mL})$ under argon was added methyltriphenylphosphonium bromide $(2.05 \mathrm{~g}, 5.7 \mathrm{mmol})$. The mixture was sonicated in a ColePalmer 8852 ultrasound bath $(352 \mathrm{~W})$ at room temperature for $1.5 \mathrm{~h}$, degassed under vacuum (0.5 Torr) with stirring for $30 \mathrm{~min}$, and then centrifuged to remove the salts. The resulting ylide solution was used without further treatment in the Wittig olefination reaction.

\subsection{Wittig reaction with methilidenetriphenylphosphorane (general procedure)}

To a solution of the corresponding aldehyde or ketone $(1.5 \mathrm{mmol})$ in anhydrous toluene $(5 \mathrm{~mL})$ under argon was added the 
solution of the salt-free ylide $(1.5 \mathrm{mmol})$. The mixture was stirred at room temperature for $1 \mathrm{~h}$ and directly applied to a flash chromatography column (silica gel), elution with ethyl acetate/hexanes mixtures of increasing polarity gave the corresponding alkenes.

\subsection{Microwave assisted metathesis dimerization (general procedure)}

To a solution of the corresponding monomeric alkene in anhydrous dichloromethane $(0.3 \mathrm{M})$ was added Grubbs 2 nd generation catalyst $(2.5 \% \mathrm{~mol})$ at room temperature under argon. The reaction tube was sealed and irradiated in a microwave reactor at the indicated temperature for the appropriate time. All microwave irradiations were carried out at $300 \mathrm{~W}$, in a closed vessel, with power max on. The reaction mixture was directly applied to a flash chromatography column on silica gel and eluted with ethyl acetate/ hexanes mixtures to give the corresponding dimers.

\subsubsection{3 -Acetyloxy-20-methylidenepregnane (1)}

Prepared from pregnanolone acetate $(323 \mathrm{mg}, 0.9 \mathrm{mmol})$ following the general methodology for the Wittig reaction compound 1 was obtained as a white solid (281 mg, 87\%). Mp 110-112 ${ }^{\circ} \mathrm{C}$; IR $\left(\mathrm{KBr}, \mathrm{cm}^{-1}\right) 2934,2909,2843,1732,1632,1266,1033,889 ;{ }^{1} \mathrm{H}$ NMR $\left(500 \mathrm{MHz}, \mathrm{CDCl}_{3}\right) \delta 4.84(\mathrm{t}, 1 \mathrm{H}, J=1.4 \mathrm{~Hz}, 22 \mathrm{a}-\mathrm{H}), 4.69(\mathrm{~m}, 2 \mathrm{H}, 22-\mathrm{Hb}$ and 3-H), $2.02(\mathrm{~m}, 3 \mathrm{H}$, acetate), $1.75(\mathrm{~s}, 3 \mathrm{H}, 21-\mathrm{H}), 0.82(\mathrm{~s}, 3 \mathrm{H}, 19-\mathrm{H})$, 0.56 (s, 3H, 18-H); $\left.{ }^{13} \mathrm{C} \mathrm{NMR} \mathrm{(125} \mathrm{MHz,} \mathrm{CDCl}_{3}\right) \delta 170.7$ (COO), 145.8 (C-20), 110.6 (C-22), 73.8 (C-3), 57.3 (C-17), 56.2 (C-14), 54.4 (C-9), 44.7 (C-5), 43.3 (C-13), 38.9 (C-1), 36.8 (C-12), 35.8 (C-8), 35.5 (C10), 34.0 (C-4), 31.9 (C-7), 28.6 (C-6), 27.5 (C-2), 25.4 (C-21), 24.7 (C15), 24.2 (C-16), 21.5 ( $\left.\mathrm{CH}_{3} \mathrm{COO}\right), 21.3$ (C-11), 12.9 (C-19), 12.3 (C-18). Anal. Calcd for $\mathrm{C}_{24} \mathrm{H}_{38} \mathrm{O}_{2}$ : C, 80.4; $\mathrm{H}, 10.7 \%$. Found: $\mathrm{C}, 80.1 ; \mathrm{H}, 10.8 \%$; MS (EI) $m / z 358(\mathrm{M})^{+}, 298$ (M-acetate), 283, 229, 215, 149, 133, 119, $107,93,81,55,43$.

\subsection{2. $3 \alpha, 12 \alpha$-Diacetoxy-5 $\beta H$-22-cholene (3)}

A solution of $2(5.4 \mathrm{~g}, 8.75 \mathrm{mM}), \mathrm{Cu}(\mathrm{AcO})_{2}(422 \mathrm{mg}, 1.75 \mathrm{mmol})$, and pyridine $(0.66 \mathrm{~mL})$ in anhydrous toluene $(53 \mathrm{~mL})$ under argon was stirred at room temperature for $15 \mathrm{~min}$. The mixture was heated under reflux and iodobenzene diacetate was added portionwise every $90 \mathrm{~min}(5 \times 430 \mathrm{mg}, 5 \mathrm{mmol})$. After the addition was completed heating was continued for $8 \mathrm{~h}$. The reaction mixture was cooled to room temperature and extracted with $5 \% \mathrm{HCl}$. The organic layer was washed with water, dried over anhydrous $\mathrm{Na}_{2} \mathrm{SO}_{4}$, filtered, and the solvent evaporated. The residue was purified by flash column chromatography on silica gel with hexane/ethyl acetate mixtures to give 3 as a white solid $(2.8 \mathrm{~g}, 57 \%)$. Further elution gave a second fraction of unreacted $\mathbf{1}$ (648 $\mathrm{mg}, 12 \%)$. Spectroscopic data of compound $3\left({ }^{1} \mathrm{H}\right.$ NMR, IR) was identical to that found in literature. ${ }^{23}$

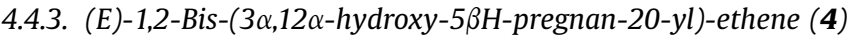

Method A. Prepared from 3 (25 $\mathrm{mg}, 0.06 \mathrm{mmol}$ ) following the MW assisted metathesis general methodology compound $\mathbf{4}$ was obtained as a white solid ( $24 \mathrm{mg}, 97 \%$ ).

Method $B$. Alternatively, 4 was prepared by adding Grubbs-type second generation catalyst ( $20 \mathrm{~mol} \%)$ to a solution of $3(128 \mathrm{mg}$, $0.30 \mathrm{mmol})$ in anhydrous dichloromethane $(0.2 \mathrm{M})$ at room temperature under argon. The reaction mixture was then stirred for $6.5 \mathrm{~h}$ and directly applied to a flash chromatography column (silica gel) to afford 4 (65 mg, 52\%) and unreacted 3 (50 mg, 39\%). Mp 201$202{ }^{\circ} \mathrm{C}$; IR $\left(\mathrm{KBr}, \mathrm{cm}^{-1}\right) \nu 2940,2857,1729,1234,1125 ;{ }^{1} \mathrm{H}$ NMR $\left(500 \mathrm{MHz}, \mathrm{CDCl}_{3}\right) \delta 5.08(\mathrm{~m}, 1 \mathrm{H}, 22-\mathrm{H}), 5.06(\mathrm{~m}, 1 \mathrm{H}, 12-\mathrm{H}), 4.71(\mathrm{~m}$, $1 \mathrm{H}, 3-\mathrm{H}), 2.11$ (s, 3H, acetate), $2.04(\mathrm{~s}, 3 \mathrm{H}$, acetate), $0.91(\mathrm{~s}, 3 \mathrm{H}, 19-\mathrm{H})$, $0.86(\mathrm{~d}, J=6.7 \mathrm{~Hz}, 3 \mathrm{H}, 21-\mathrm{H}), 0.73$ (s, 3H, 18-H); ${ }^{13} \mathrm{C} \mathrm{NMR}(125 \mathrm{MHz}$, $\left.\mathrm{CDCl}_{3}\right) \delta 170.6(\mathrm{COO}), 170.5(\mathrm{COO}), 134.2(\mathrm{C}-22), 75.8$ (C-12), $74.2(\mathrm{C}-$ 3), 49.5 (C-14), 47.8 (C-17), 44.9 (C-13), 41.9 (C-5), 39.4 (C-20), 35.7 (C-9), 34.8 (C-10), 34.5 (C-1), 34.1 (C-8), 32.3 (C-4), 27.9 (C-2), 26.9
(C-6), 26.7 (C-7), 25.9 (C-16), 25.7 (C-11), 23.6 (C-15), 23.1 (C-19), $21.5\left(\mathrm{CH}_{3} \mathrm{COO}\right), 21.4\left(\mathrm{CH}_{3} \mathrm{COO}\right), 20.4$ (C-21), 12.7 (C-18); HRMS (ESI) calcd for $\mathrm{C}_{52} \mathrm{H}_{80} \mathrm{O}_{8} \mathrm{Na}\left(\mathrm{MNa}^{+}\right)$: 855.5745, found: 855.5729 .

\subsubsection{3,20-Dioxo-5 $\beta$ H-cholan-24-al (6)}

To a solution of $3 \alpha, 12 \alpha$-dihydroxy- $5 \beta$-cholanic acid methyl ester $(5,500 \mathrm{mg}, 1.23 \mathrm{mmol})$ in anhydrous THF $(25 \mathrm{~mL})$ was added $\mathrm{LiAlH}_{4}$ (93 $\mathrm{mg}, 2.46 \mathrm{mmol}$ ) at $0{ }^{\circ} \mathrm{C}$ under argon. The reaction mixture was stirred for $15 \mathrm{~min}$ at room temperature and quenched by successively adding acetone, $\mathrm{HCl} 10 \%$, and sodium and potassium tartrate saturated solution. The mixture was concentrated in vacuo, the residue was dissolved in dichloromethane, and washed with aqueous sodium bicarbonate, brine, and water. The organic layer was dried over anhydrous $\mathrm{Na}_{2} \mathrm{SO}_{4}$, filtered, and the solvent evaporated to give $3 \alpha, 12 \alpha, 24-5 \beta \mathrm{H}$-cholanetriol. The crude triol was oxidized without further purification with PCC $(1.2 \mathrm{~g}, 5.54 \mathrm{mmol})$, barium carbonate $(631 \mathrm{mg}, 3.20 \mathrm{mmol})$, and $4 \AA$ molecular sieves in anhydrous dichloromethane $(20 \mathrm{~mL})$ at room temperature under a nitrogen atmosphere for $30 \mathrm{~min}$. The reaction was diluted with diethyl ether and the mixture was concentrated in vacuo. The residue was redissolved in diethyl ether and the resulting solution was applied to a flash chromatography column (Florisil) and eluted with diethyl ether to give $\mathbf{6}$ (368 $\mathrm{mg}, 83 \%$ ) as a crystalline solid. Mp $108-110{ }^{\circ} \mathrm{C}$; IR $\left(\mathrm{KBr}, \mathrm{cm}^{-1}\right) \nu 2967,1707,1657,1460,1083,1219,891 ;{ }^{1} \mathrm{H}$ NMR $\left(500 \mathrm{MHz}, \mathrm{CDCl}_{3}\right) \delta 9.78(\mathrm{t}, 1 \mathrm{H}, J=1.7 \mathrm{~Hz}, 24-\mathrm{H}), 2.59$ (dd, $J=15.0$, $13.2 \mathrm{~Hz}, 1 \mathrm{H}, 4 \alpha-\mathrm{H}$ ), 2.50 (ddd, $J=9.5,5.4,0.8 \mathrm{~Hz}, 1 \mathrm{H}, 23 \mathrm{a}-\mathrm{H}$ ), 2.43 (dt, $J=7.7,1.0 \mathrm{~Hz}, 1 \mathrm{H}, 23 \mathrm{~b}-\mathrm{H}$ ), 2.33 (dd, $J=14.7,5.4 \mathrm{~Hz}, 1 \mathrm{H}, 2 \mathrm{a}-\mathrm{H}), 2.19$ (ddd, $J=14.7,6.4,3.1 \mathrm{~Hz}, 1 \mathrm{H}, 2 \mathrm{~b}-\mathrm{H}$ ), 1.12 (s, 3H, 19-H), 1.06 (s, 3H, 18$\mathrm{H}), 0.86(\mathrm{~d}, J=6.6 \mathrm{~Hz}, 3 \mathrm{H}, 21-\mathrm{H}) ;{ }^{13} \mathrm{C} \mathrm{NMR}\left(125 \mathrm{MHz}, \mathrm{CDCl}_{3}\right) \delta 214.1$ (C-12), 212.1 (C-3), 203.0 (C-24), 58.5 (C-9), 57.6 (C-13), 46.5 (C-17), 44.3 (C-14), 43.7 (C-5), 42.1 (C-4), 41.2 (C-23), 38.4 (C-11), 36.9 (C-2), 36.8 (C-1), 35.6 (C-10), 35.6 (C-20), 35.4 (C-8), 27.6 (C-22), 27.4 and 26.6 (C-7, C-15), 25.5 (C-6), 24.3 (C-16), 22.1 (C-19), 18.7 (C-21), 11.7 (C-18). Anal. Calcd for $\mathrm{C}_{24} \mathrm{H}_{36} \mathrm{O}_{3}$ : C, 77.4; $\mathrm{H}, 9.7 \%$. Found: $\mathrm{C}, 77.3 ; \mathrm{H}$, 9.7\%; MS (EI) $m / z 372(\mathrm{M})^{+}, 354,344,329,247,121,107,93,81,55,41$

\subsection{5. $5 \beta \mathrm{H}$-24-Cholene-3,12-dione (7)}

Prepared from 3,20-dioxo-5 $\beta \mathrm{H}$-cholan-24-al (6) $(500 \mathrm{mg}$, $1.35 \mathrm{mmol}$ ) following the general Wittig methodology described above compound $\mathbf{7}$ was obtained as a white crystalline solid (424 mg, 85\%). Mp 121-122 ${ }^{\circ} \mathrm{C}$; IR $\left(\mathrm{KBr}, \mathrm{cm}^{-1}\right) \nu$ 2970, 2948, 2906, 2869, 1709, 1507, 1452, 1028; ${ }^{1} \mathrm{H}$ NMR (500 MHz, $\left.\mathrm{CDCl}_{3}\right) \delta 5.79$ (ddt, $J=17.1,10.2,6.7 \mathrm{~Hz}, 1 \mathrm{H}, 24-\mathrm{H}), 4.98$ (ddt, $J=17.2,2.0,1.7 \mathrm{~Hz}, 1 \mathrm{H}, 25 \mathrm{a}-$ $\mathrm{H}$ ), 4.91 (ddt, $J=10.1,2.1,1.2 \mathrm{~Hz}, 1 \mathrm{H}, 25 \mathrm{~b}-\mathrm{H}), 2.61$ (t, $J=12.5 \mathrm{~Hz}, 1 \mathrm{H}$, $11 \beta-\mathrm{H}$ ), 2.59 (dd, $J=14.8,13.6 \mathrm{~Hz}, 1 \mathrm{H}, 4 \alpha-\mathrm{H}), 1.11(\mathrm{~s}, 3 \mathrm{H}, 19-\mathrm{H}), 1.05$ (s, $3 \mathrm{H}, 18-\mathrm{H}), 0.86(\mathrm{~d}, J=6.6 \mathrm{~Hz}, 3 \mathrm{H}, 21-\mathrm{H}) ;{ }^{13} \mathrm{C} \mathrm{NMR}\left(125 \mathrm{MHz}, \mathrm{CDCl}_{3}\right)$ o 214.2 (C-12), 212.1 (C-3), 139.5 (C-24), 114.1 (C-25), 58.6 (C-9), 57.6 (C-13), 46.8 (C-17), 44.3 (C-14), 43.7 (C-5), 42.1 (C-4), 38.4 (C-11), 36.9 (C-2), 36.8 (C-1), 35.7 (C-20), 35.6 (C-10), 35.5 (C-8), 34.8 (C22), 30.9 (C-23), 27.6 and 26.6 (C-7, C-15), 25.5 (C-6), 24.4 (C-16), 22.2 (C-19), 18.8 (C-21), 11.7 (C-18). Anal. Calcd for $\mathrm{C}_{25} \mathrm{H}_{38} \mathrm{O}_{2}$ : C, 81.0; H, 10.3\%. Found: C, 81.0; H, 10.3\%; MS (EI) $m / z 370(\mathrm{M})^{+}, 355$, 337, 328 (M-ketene), 273, 247, 135, 121, 107, 93, 81, 55, 41.

\subsubsection{0-Ethenyl-4-pregnen-3-one (9)}

Prepared from 3-oxo-4-pregnen-20 $\beta$-carboxyaldehyde (8 $500 \mathrm{mg}, 1.5 \mathrm{mmol}$ ) following the general Wittig methodology described above compound $\mathbf{9}$ was obtained as a white crystalline solid (426 mg, 87\%). Mp $116-117^{\circ} \mathrm{C}$; IR $\left(\mathrm{KBr}, \mathrm{cm}^{-1}\right) \nu 2951,2865,2843$, $1671,1452,1230,911,864 ;{ }^{1} \mathrm{H}$ NMR $\left(500 \mathrm{MHz}, \mathrm{CDCl}_{3}\right) \delta 5.72(\mathrm{~s}, 1 \mathrm{H}$, 4-H), 5.66 (ddd, $J=17.1,10.2,8.4 \mathrm{~Hz}, 1 \mathrm{H}, 22-\mathrm{H}$ ), 4.91 (dd, $J=17.1$, $2.0 \mathrm{~Hz}, 1 \mathrm{H}, 23 \mathrm{a}-\mathrm{H}$ ), 4.82 (dd, $J=10.2,2.0 \mathrm{~Hz}, 1 \mathrm{H}, 23 \mathrm{~b}-\mathrm{H}), 1.19$ (s, 3H, 19-H), 1.04 (d, $J=6.6 \mathrm{~Hz}, 3 \mathrm{H}, 21-\mathrm{H}), 0.74(\mathrm{~s}, 3 \mathrm{H}, 18-\mathrm{H}) ;{ }^{13} \mathrm{C}$ NMR $\left(125 \mathrm{MHz}, \mathrm{CDCl}_{3}\right) \delta 199.6(\mathrm{C}-3), 171.6(\mathrm{C}-5), 145.1(\mathrm{C}-22), 123.8(\mathrm{C}-4)$, 111.7 (C-23), 55.9 (C-14), 55.4 (C-17), 53.8 (C-9), 42.4 (C-13), 41.2 (C20), 39.5 (C-12), 38.6 (C-10), 35.7 (C-1), 35.6 (C-8), 34.0 (C-2), 32.9 
(C-6), 32.0 (C-7), 28.3 (C-16), 24.2 (C-15), 21.0 (C-11), 20.1 (C-21), 17.4 (C-19), 12.2 (C-18). Anal. Calcd for $\mathrm{C}_{23} \mathrm{H}_{34} \mathrm{O}$ : C, 84.6; $\mathrm{H}, 10.5 \%$. Found: C, 84.6; H, 10.8\%; MS (EI) $m / z 326(\mathrm{M})^{+}, 298,284$ (M-ketene), 269, 229, 203, 147, 133, 124, 107, 91, 79, 55, 41.

\subsubsection{1,4-Bis-(3,12-dioxo-5 $\beta$ H-pregnan-20-yl)-2E-butene (10)}

Prepared from 7 ( $20 \mathrm{mg}, 0.05 \mathrm{mmol}$ ) following the general MW assisted metathesis methodology compound $\mathbf{1 0}$ was obtained as a white solid (16 mg, 89\%). Mp 246-249 ${ }^{\circ} \mathrm{C}$; IR $\left(\mathrm{KBr}, \mathrm{cm}^{-1}\right) \nu 2926$, 2862, 2249, 1705, 1646, 1460, 1383, 1272, 919; ${ }^{1} \mathrm{H}$ NMR (500 MHz, $\left.\mathrm{CDCl}_{3}\right) \delta 5.38(\mathrm{~m}, 1 \mathrm{H}, 24-\mathrm{H}), 2.62(2 \mathrm{H}, \mathrm{m}, 4 \alpha-\mathrm{H}$ and $11-\mathrm{H} \beta), 1.12(\mathrm{~s}, 3 \mathrm{H}$, 19-H), 1.06 (s, 3H, 18-H), 0.86 (d, $J=6.6 \mathrm{~Hz}, 3 \mathrm{H}, 21-\mathrm{H}) ;{ }^{13} \mathrm{C}$ NMR $\left(125 \mathrm{MHz}, \mathrm{CDCl}_{3}\right) \delta 214.3(\mathrm{C}-12), 212.2(\mathrm{C}-3), 130.5(\mathrm{C}-24), 58.6(\mathrm{C}-9)$, 57.6 (C-13), 46.8 (C-17), 44.3 (C-14), 43.7 (C-5), 42.2 (C-4), 38.4 (C$11), 36.9(\mathrm{C}-2), 36.8(\mathrm{C}-1), 35.8(\mathrm{C}-20), 35.6(\mathrm{C}-10), 35.5(\mathrm{C}-8), 35.5(\mathrm{C}-$ 22), 29.7 (C-23), 27.6 and 26.6 (C-7, C15), 25.5 (C-6), 24.4 (C-16), 22.2 (C-19), 18.9 (C-21), 11.8 (C-18). Anal. Calcd for $\mathrm{C}_{48} \mathrm{H}_{72} \mathrm{O}_{4}$ : C, 80.9; $\mathrm{H}$, 10.2\%. Found: C, 81.0; H, 10.3\%; MS (EI) $\mathrm{m} / z 671$ (M-ketene), 626, 591, 491, 336, 312, 284, 269, 243, 215, 145, 105, 91, 79, 55, 40.

\subsection{8. (E)-1,2-Bis-(3-oxo-4-pregnen-20-yl)-ethene (11)}

Prepared from $9(82 \mathrm{mg}, 0.25 \mathrm{mmol})$ following the general MW assisted metathesis methodology, after chromatography (silica gel, ethyl acetate/hexanes) compound $\mathbf{1 1}$ was obtained as a white solid (38 mg, 49\%). Mp 250-254 ${ }^{\circ} \mathrm{C}$ (dec); IR $\left(\mathrm{KBr}, \mathrm{cm}^{-1}\right) \nu$ 2968, 2937, 2865, 1635, 1458, 1269, 1227; ${ }^{1} \mathrm{H}$ NMR $\left(500 \mathrm{MHz}, \mathrm{CDCl}_{3}\right) \delta 5.73(\mathrm{~s}$, $1 \mathrm{H}, 4-\mathrm{H}), 5.11(\mathrm{~m}, 1 \mathrm{H}, 22-\mathrm{H}), 1.19$ (s, 3H, 19-H), 0.98 (d, J=6.6 Hz, 3H, 21-H), 0.72 (s, 3H, 18-H); ${ }^{13} \mathrm{C} \mathrm{NMR} \mathrm{(125} \mathrm{MHz,} \mathrm{CDCl} 3$ ) $\delta 199.7$ (C-3), 171.7 (C-5), 134.3 (C-22), 123.8 (C-4), 56.0 (C-14, C-17), 53.8 (C-9), 42.3 (C-13), 40.1 (C-20), 39.5 (C-12), 38.6 (C-10), 35.7 (C-1), 35.6 (C8), 34.0 (C-2), 33.0 (C-6), 32.0 (C-7), 28.8 (C-16), 24.3 (C-15), 21.0 (C11), 20.9 (C-21), 17.4 (C-19), 12.1 (C-18). Anal. Calcd for $\mathrm{C}_{44} \mathrm{H}_{64} \mathrm{O}_{2}$ : C, 84.6; H, 10.3\%. Found: C, 84.4; H, 10.4\%; MS (EI) $m / z 624(\mathrm{M})^{+}, 609$, 582 (M-ketene), 269, 147, 131, 119, 107, 95, 81, 55, 41. Further elution rendered a fraction of unreacted $\mathbf{9}(8 \mathrm{mg}, 10 \%)$.

\subsubsection{0 $\beta$-Acetyloxy-5 $\alpha H$-2-pregnen-6-one (12)}

Prepared from pregnenolone acetate $(200 \mathrm{mg}, 0.56 \mathrm{mmol})$ using the method described by Mori et al. ${ }^{28}$ compound 12 was obtained as an amorphous solid (164 mg, 82\%). IR $\left(\mathrm{KBr}, \mathrm{cm}^{-1}\right) \nu 2942,2906$, $1730,1708,1433,1373,1075,1024 ;{ }^{1} \mathrm{H}$ NMR $\left(500 \mathrm{MHz}, \mathrm{CDCl}_{3}\right) \delta 5.69$ (m, 1H, 3-H), $5.56(\mathrm{~m}, 1 \mathrm{H}, 2-\mathrm{H}), 4.85$ (br s, 1H, 20-H), $2.02(\mathrm{~s}, 3 \mathrm{H}$, acetate), $1.16(\mathrm{~d}, J=5.8 \mathrm{~Hz}, 3 \mathrm{H}, 21-\mathrm{H}), 0.71(\mathrm{~s}, 3 \mathrm{H}, 19-\mathrm{H}), 0.65(\mathrm{~s}, 3 \mathrm{H}$, 18-H); ${ }^{13} \mathrm{C}$ NMR (125 MHz, $\mathrm{CDCl}_{3}$ ) $\delta 211.6$ (C-6), 170.3 (COO), 125.0 (C-2), 124.5 (C-3), 72.7 (C-20), 56.1 (C-14), 54.9 (C-17), 53.9 (C-9), 53.5 (C-5), 46.9 (C-7), 42.6 (C-13), 40.0 (C-10), 39.4 (C-1), 39.0 (C12), 37.5 (C-8), 25.2 (C-16), 24.0 (C-15), $21.6(\mathrm{C}-4), 21.5\left(\mathrm{CH}_{3} \mathrm{COO}\right)$, 21.0 (C-11), 19.9 (C-21), 13.5 (C19), 12.5 (C-18); MS (ESI) m/z 381 $(\mathrm{M}+\mathrm{Na})^{+}, 359(\mathrm{M}+\mathrm{H})^{+}, 298,105,93,81,55,43$. Anal. Calcd for $\mathrm{C}_{23} \mathrm{H}_{34} \mathrm{O}_{3}$ : C, 77.0; $\mathrm{H}, 9.6 \%$. Found: $\mathrm{C}, 76.6$; $\mathrm{H}, 9.3 \%$.

\subsubsection{0ß-Acetyloxy-5 $\alpha$ H-pregnan-6-one (13)}

$20 \beta$-Acetyloxy-5 $\alpha \mathrm{H}$-2-pregnen-6-one $(\mathbf{1 2}, 150 \mathrm{mg}, 0.42 \mathrm{mmol})$ was dissolved in ethyl acetate $(15 \mathrm{~mL}), 10 \% \mathrm{Pd} / \mathrm{C}(15 \mathrm{mg})$ added and the mixture hydrogenated at 3 bar for $8 \mathrm{~h}$. The catalyst was filtered and the residue purified by column chromatography (silica gel, ethyl acetate/hexanes) to give $\mathbf{1 3}$ as a white solid (148 mg, 98\%). Mp 163-165 ${ }^{\circ} \mathrm{C}$; IR $\left(\mathrm{KBr}, \mathrm{cm}^{-1}\right) \nu 2981,2937,2873,1732,1646,1372$, $1244,1075,1019,877 ;{ }^{1} \mathrm{H}$ NMR $\left(500 \mathrm{MHz}, \mathrm{CDCl}_{3}\right) \delta 4.83$ (dq, $J=6.0$, $10.6 \mathrm{~Hz}, 1 \mathrm{H}, 20-\mathrm{H}$ ), 2.28 (dd, $J=4.5,13.1 \mathrm{~Hz}, 1 \mathrm{H}, 7 \mathrm{a}-\mathrm{H}$ ), 2.13 (dd, $J=3.2,12.3 \mathrm{~Hz}, 1 \mathrm{H}, 5-\mathrm{H}), 2.02(\mathrm{~s}, 3 \mathrm{H}$, acetate), 1.15 (d, $J=6.1 \mathrm{~Hz}, 3 \mathrm{H}$, 21-H), 0.72 (s, 3H, 19-H), 0.62 (s, 3H, 18-H); ${ }^{13} \mathrm{C}$ NMR $(125 \mathrm{MHz}$, $\left.\mathrm{CDCl}_{3}\right) \delta 212.5$ (C-6), 170.4 (COO), 72.7 (C-20), 58.9 (C-5), 56.2 (C14), 54.9 (C-17), 54.4 (C-9), 46.8 (C-7), 42.8 (C-13), 41.8 (C-10), 39.0 (C-12), 38.2 (C-1), 37.8 (C-8), 25.3 (C-16), 25.2 (C-15), 24.0 (C-3), 21.5 ( $\left.\mathrm{CH}_{3} \mathrm{COO}\right), 21.4$ (C-2), 21.1 (C-11), 20.5 (C-4), 19.9 (C-21), 13.1 (C-19),
12.5 (C-18); MS (EI) m/z 360 (M) ${ }^{+}, 300,285,124,107,95,81,55,43$. Anal. Calcd for $\mathrm{C}_{23} \mathrm{H}_{36} \mathrm{O}_{3}$ : C, 76.6; $\mathrm{H}, 10.1 \%$. Found: $\mathrm{C}, 76.8 ; \mathrm{H}, 10.1 \%$.

4.4.11. $6 \beta$-Hydroxy-6 $\alpha$-(1-propenyl)-5 $\alpha H$-pregnan-20-one (16) and $6 \alpha$-hydroxy-6 $\beta$-(1-propenyl)-5 $\alpha H$-pregnan-20-one (17)

To a solution of allylmagnesium chloride (2.0 M in THF, $1.2 \mathrm{~mL}$ ) at $0{ }^{\circ} \mathrm{C}$ was added a solution of $20 \beta$-acetyloxy-6-methylidene- $5 \alpha \mathrm{H}$ pregnane $(13,200 \mathrm{mg}, 0.56 \mathrm{mmol})$ in THF $(0.8 \mathrm{~mL})$. The mixture was stirred at room temperature for $30 \mathrm{~min}$ and quenched with saturated aqueous $\mathrm{NH}_{4} \mathrm{Cl}(1 \mathrm{~mL})$. The solvent was evaporated and the residue was dissolved in dichloromethane $(5 \mathrm{~mL})$. The organic layer was washed with water $(5 \mathrm{~mL})$ and dried over anhydrous $\mathrm{Na}_{2} \mathrm{SO}_{4}$, filtered, and the solvent evaporated. The residue was purified by flash column chromatography (silica gel, hexane/ethyl acetate) to give the mixture of $6 \alpha-\mathrm{OH}$ and $6 \beta-\mathrm{OH}$ isomers of $5 \alpha-\mathrm{H}-$ 20ß,6-dihydroxy-6-(1-propenyl) ( $8: 2$ ratio, $170 \mathrm{mg}, 84 \%$ ). An analytical sample of $6 \beta-\mathrm{OH}$ isomer 14: ${ }^{1} \mathrm{H}$ NMR $\left(500 \mathrm{MHz}, \mathrm{CDCl}_{3}\right) \delta 5.76$ (ddt, $1 \mathrm{H}, J=17.1,7.5,10.0 \mathrm{~Hz}, 1 \mathrm{H}, 23-\mathrm{H}$ ), 5.07 (dd, $J=9.9,2.2 \mathrm{~Hz}, 1 \mathrm{H}$, 24b-H), 5.05 (dd, J=16.8, $2.5 \mathrm{~Hz}, 1 \mathrm{H}, 24 \mathrm{a}-\mathrm{H}$ ), 2.22 (dd, $J=14.0,7.9 \mathrm{~Hz}$, $1 \mathrm{H}, 22 \mathrm{a}-\mathrm{H}$ ), 2.17 (dd, $J=13.7,7.7 \mathrm{~Hz}, 1 \mathrm{H}, 22 \mathrm{~b}-\mathrm{H}), 1.14$ (d, $J=6.1 \mathrm{~Hz}, 3 \mathrm{H}$, 21-H), 1.02 (s, 3H, 19-H), 0.77 (s, 3H, 18-H); ${ }^{13} \mathrm{C} \mathrm{NMR} \mathrm{(125} \mathrm{MHz,}$ $\left.\mathrm{CDCl}_{3}\right) \delta 134.4(\mathrm{C}-23), 118.0$ (C-24), 73.7 (C-6), 70.6 (C-20), 58.6 (C17), 55.7 (C-14), 54.3 (C-9), 50.9 (C-5), 46.9 (C-22), 43.1 (C-7), 42.5 (C-13), 40.8 (C-1), 40.2 (C-12), 36.7 (C-10), 30.8 (C-8), 26.9 (C-3), 25.6 (C-15), 24.4 (C-16), 23.6 (C-21), 21.8 (C-2), 20.5 (C-11), 20.4 (C4), 15.5 (C-19), 12.6 (C-18). Anal. Calcd for $\mathrm{C}_{24} \mathrm{H}_{40} \mathrm{O}_{2}$ : C, 79.9; $\mathrm{H}$, $11.2 \%$. Found: $\mathrm{C}, 79.9 ; \mathrm{H}, 11.1 \%$. An analytical sample of $6 \alpha-\mathrm{OH}$ isomer 15: ${ }^{1} \mathrm{H}$ NMR (500 MHz, $\left.\mathrm{CDCl}_{3}\right) \delta 5.86$ (dddd, $J=17.4,9.9,6.9$, $8.1 \mathrm{~Hz}, 1 \mathrm{H}, 23-\mathrm{H}), 5.19$ (dd, $J=10.2,2.3 \mathrm{~Hz}, 1 \mathrm{H}, 24 \mathrm{~b}-\mathrm{H}), 5.14$ (dd, $J=17.1,2.3 \mathrm{~Hz}, 1 \mathrm{H}, 24 \mathrm{a}-\mathrm{H}), 3.74(\mathrm{~m}, 1 \mathrm{H}, 20-\mathrm{H}), 2.29$ (dd, $J=13.7$, $6.7 \mathrm{~Hz}, 1 \mathrm{H}, 22 \mathrm{a}-\mathrm{H}), 1.97$ (dd, $J=13.7,8.1 \mathrm{~Hz}, 1 \mathrm{H}, 22 \mathrm{~b}-\mathrm{H}), 1.13$ (d, $J=6.1 \mathrm{~Hz}, 3 \mathrm{H}, 21-\mathrm{H}), 1.12(\mathrm{~s}, 3 \mathrm{H}, 19-\mathrm{H}), 0.76(\mathrm{~s}, 3 \mathrm{H}, 18-\mathrm{H}) ;{ }^{13} \mathrm{C}$ NMR $\left(125 \mathrm{MHz}, \mathrm{CDCl}_{3}\right) \delta 133.4(\mathrm{C}-23), 119.4(\mathrm{C}-24), 75.0(\mathrm{C}-6), 70.6(\mathrm{C}-$ 20), 58.7 (C-17), 55.8 (C-14), 52.2 (C-5), 46.4 (C-22), 42.7 (C-13), 41.1 (C-9), 40.3 (C-12), 39.7 (C-7), 38.8 (C-1), 36.3 (C-10), 32.0 (C-8), 27.7 (C-19), 26.9 (C-3), 25.7 (C-15), 25.0 (C-4), 24.5 (C-16), 23.6 (C-21), 20.9 (C-2), 20.5 (C-11), 12.6 (C-18). Anal. Calcd for $\mathrm{C}_{24} \mathrm{H}_{40} \mathrm{O}_{2}$ : C, 79.9; $\mathrm{H}, 11.2 \%$. Found: $\mathrm{C}, 79.8$; $\mathrm{H}, 11.2 \%$.

The mixture of $6 \alpha$ and $6 \beta$ isomers obtained above $(170 \mathrm{mg}$, $0.47 \mathrm{mmol}$ ) was oxidized with PCC $(253 \mathrm{mg}, 0.94 \mathrm{mmol})$, barium carbonate (172 mg, $0.71 \mathrm{mmol}$ ), and $4 \AA$ molecular sieves in anhydrous dichloromethane $(15 \mathrm{~mL})$ at room temperature under a nitrogen atmosphere for $45 \mathrm{~min}$. The reaction was diluted with diethyl ether, concentrated in vacuo, and the residue purified by flash column chromatography on silica gel (hexanes/ethyl acetate) to give in order of elution: $6 \alpha$-hydroxy- $6 \beta-(1$-propenyl)- $5 \alpha \mathrm{H}$ pregnan-20-one $(\mathbf{1 7}, 15 \mathrm{mg}, 9 \%)$, a mixed fraction $(\mathbf{1 6}+\mathbf{1 7}, 8 \mathrm{mg})$ and $6 \beta$-hydroxy-6 $\alpha$-(1-propenyl)-5 $\alpha \mathrm{H}$-pregnan-20-one $\quad(\mathbf{1 6}, 121 \mathrm{mg}$, 72\%). $6 \beta$-Hydroxy-6 $\alpha$-(1-propenyl)-5 $\alpha \mathrm{H}$-pregnan-20-one (16): mp 105-107 ${ }^{\circ} \mathrm{C}$; IR $\left(\mathrm{KBr}, \mathrm{cm}^{-1}\right) \nu 3406,2920,2848,1716,1457,1261$, 1096; ${ }^{1} \mathrm{H}$ NMR $\left(500 \mathrm{MHz}, \mathrm{CDCl}_{3}\right) \delta 5.75$ (ddt, $J=17.0,10.0,7.5 \mathrm{~Hz}, 1 \mathrm{H}$, 23-H), 5.08 (d, J=10.0 Hz, 1H, 24b-H), 5.04 (d, J=17.0 Hz, 1H, 24a-H), 2.12 (s, 3H, 21-H), 1.01 (s, 3H, 19-H), 0.63 (s, 3H, 18-H); ${ }^{13} \mathrm{C}$ NMR (125 MHz, $\mathrm{CDCl}_{3}$ ) $\delta 209.6$ (C-20), 134.3 (C-23), 118.1 (C-24), 73.6 (C6), 63.9 (C-17), 56.5 (C-14), 54.2 (C-9), 50.9 (C-5), 46.9 (C-22), 44.2 (C-13), 43.0 (C-7), 40.8 (C-1), 39.1 (C-12), 36.7 (C-10), 31.5 (C-21), 31.0 (C-8), 26.9 (C-2), 24.4 (C-15), 22.8 (C-16), 21,8 (C-11), 20.7 and 20.4 (C-4, C-3), 15.5 (C-19), 13.5 (C-18); MS (EI) m/z $358\left(\mathrm{M}^{+}\right), 340$ $\left(\mathrm{M}-\mathrm{H}_{2} \mathrm{O}\right), 317\left(\mathrm{M}-\mathrm{C}_{3} \mathrm{H}_{5}\right), 299,281,189,161,107,81,55$, 43. Anal. Calcd for $\mathrm{C}_{24} \mathrm{H}_{38} \mathrm{O}_{2} \cdot 1 / 2 \mathrm{H}_{2} \mathrm{O}$ : C, $78.1 ; \mathrm{H}, 10.8 \%$. Found: $\mathrm{C}, 77.9 ; \mathrm{H}$, $10.5 \%{ }^{\dagger} \quad 6 \alpha$-Hydroxy-6 $\beta$-(1-propenyl)-5 $\alpha \mathrm{H}$-pregnan-20-one (17): amorphous solid; IR $\left(\mathrm{KBr}, \mathrm{cm}^{-1}\right) \nu 3406,2920,2848,1716,1457$,

\footnotetext{
$\dagger$ Attempts to further dry these compounds failed; the content of water was determined based on found and calculated elemental analysis data.
} 
1261, 1096; ${ }^{1} \mathrm{H}$ NMR (500 MHz, $\left.\mathrm{CDCl}_{3}\right){ }^{1} \mathrm{H} \delta 5.88$ (dddd, $J=17.3,9.9$, 7.7, $5.5 \mathrm{~Hz}, 1 \mathrm{H}, 23-\mathrm{H}$ ), 5.22 (dd, $J=10.2,2.1 \mathrm{~Hz}, 1 \mathrm{H}, 24 \mathrm{~b}-\mathrm{H}$ ), 5.17 (dd, $J=17.1,2.0 \mathrm{~Hz}, 1 \mathrm{H}, 24 \mathrm{a}-\mathrm{H}), 2.56(\mathrm{t}, J=8.9 \mathrm{~Hz}, 1 \mathrm{H}, 17-\mathrm{H}), 2.14(\mathrm{~s}, 3 \mathrm{H}$, $21 \mathrm{H}), 1.14(\mathrm{~s}, 3 \mathrm{H}, 19-\mathrm{H}), 0.65(\mathrm{~s}, 3 \mathrm{H}, 18-\mathrm{H}) ;{ }^{13} \mathrm{C}$ NMR $(125 \mathrm{MHz}$, $\left.\mathrm{CDCl}_{3}\right) \delta 209.9(\mathrm{C}-20), 133.2$ (C-23), 119.6 (C-24), 74.9 (C-6), 63.9 (C17), 56.6 (C-14), 52.1 (C-9), 46.4 (C-5), 44.5 (C-22), 41.1 (C-13), 39.6 (C-7), 39.2 (C-1), 38.8 (C-12), 36.3 (C-10), 31.5 (C-21), 30.9 (C-8), 27.6 (C-19), 26.9 (C-2), 25.0 (C-15), 24.5 (C-16), 22.9 (C-11), 20.9 (C3), 20.6 (C-4), 13.5 (C-18); MS (EI) $m / z 358\left(\mathrm{M}^{+}\right), 340\left(\mathrm{M}-\mathrm{H}_{2} \mathrm{O}\right), 317$ $\left(\mathrm{M}-\mathrm{C}_{3} \mathrm{H}_{5}\right), 299,281,189,161,107,81,55,43$. Anal. Calcd for $\mathrm{C}_{24} \mathrm{H}_{38} \mathrm{O}_{2} \cdot 1 / 2 \mathrm{H}_{2} \mathrm{O}$ : C, $78.1 ; \mathrm{H}, 10.8 \%$. Found: C, $77.8 ; \mathrm{H}, 10.4 \%$.

\subsubsection{0 $\beta$-Acetyloxy-6-methylidene-5 $\alpha H$-pregnane (18)}

Prepared from 20 $\beta$-acetyloxy-5 $\alpha \mathrm{H}$-pregnan-6-one $(\mathbf{1 3}, 250 \mathrm{mg}$, $0.69 \mathrm{mmol}$ ) using the general Wittig methodology compound $\mathbf{1 8}$ was obtained as a white solid (178 $\mathrm{mg}, 71 \%$ ). Mp $156-157^{\circ} \mathrm{C}$; IR $\left(\mathrm{KBr}, \mathrm{cm}^{-1}\right) \nu 2981,2937,2873,2862,2845,2826,1732,1646,1372$, $1244,1075,1019,877 ;{ }^{1} \mathrm{H}$ NMR $\left(500 \mathrm{MHz}, \mathrm{CDCl}_{3}\right) \delta 4.84(\mathrm{~m}, 1 \mathrm{H}, 20-$ H), 4.67 (d, $J=1.1 \mathrm{~Hz}, 1 \mathrm{H}, 22 \mathrm{a}-\mathrm{H}), 4.42$ (d, $J=1.1 \mathrm{~Hz}, 1 \mathrm{H}, 22 \mathrm{~b}-\mathrm{H}), 2.01$ (s, 3H, acetate), 1.15 (d, $J=5.8 \mathrm{~Hz}, 3 \mathrm{H}, 21-\mathrm{H}), 0.66$ (s, 3H, 18-H), 0.61 (s, 3H, 19-H); ${ }^{13} \mathrm{C}$ NMR (125 MHz, $\left.\mathrm{CDCl}_{3}\right) \delta 170.4$ (COO), 150.8 (C-6), 105.6 (C-22), 72.9 (C-20), 55.9 (C-14), 55.2 (C-9), 55.1 (C-17), 51.4 (C5), 42.5 (C-13), 42.2 (C-7), 39.3 (C-12), 38.5 (C-10), 38.3 (C-1), 37.4 (C-8), 26.4 (C-3), 25.5 (C-16), 24.3 (C-2), 24.1 (C-15), 22.0 (C-4), 21.5 ( $\mathrm{CH}_{3} \mathrm{COO}$ ), 21.0 (C-11), 19.9 (C-21), 12.6 (C-19), 12.4 (C-18); MS (EI) $\mathrm{m} / \mathrm{z} 358(\mathrm{M})^{+}, 298,229,161,147,133,122,105,93,81,55,43$. Anal. Calcd for $\mathrm{C}_{24} \mathrm{H}_{38} \mathrm{O}_{2}$ : C, 80.4; $\mathrm{H}, 10.7 \%$. Found: $\mathrm{C}, 80.2 ; \mathrm{H}, 10.8 \%$.

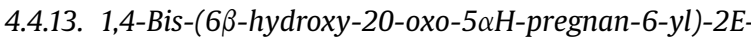

butene (19)

Prepared from $16(60 \mathrm{mg}, 0.016 \mathrm{mmol})$ following the general MW assisted metathesis methodology, after chromatography (silica gel, ethyl acetate/hexanes) homodimer 19 was obtained as a white solid (53 mg, 97\%). Mp 240-245 ${ }^{\circ} \mathrm{C}$ (dec); IR $\left(\mathrm{KBr}, \mathrm{cm}^{-1}\right) \nu 3401$, 2931, 2906, 1696, 1197, 1144, 750; ${ }^{1} \mathrm{H}$ NMR (500 MHz, $\left.\mathrm{CDCl}_{3}\right) \delta 5.38$ (dd, $J=5.1,3.4 \mathrm{~Hz}, 1 \mathrm{H}, 23-\mathrm{H}), 2.32$ (dd, $J=13.5,4.5 \mathrm{~Hz}, 1 \mathrm{H}, 22 \mathrm{a}-\mathrm{H}$ ), 2.14 (s, 3H, 21-H), 1.98 (dd, J=6.3, $13.7 \mathrm{~Hz}, 1 \mathrm{H}, 22 \mathrm{~b}-\mathrm{H}), 1.05$ (s, 3H, 19$\mathrm{H}), 0.67(\mathrm{~s}, 3 \mathrm{H}, 18-\mathrm{H}) ;{ }^{13} \mathrm{C}$ NMR $\left(125 \mathrm{MHz}, \mathrm{CDCl}_{3}\right) \delta 209.4(\mathrm{C}-20)$, 129.5 (C-23), 74.3 (C-6), 64.0 (C-17), 56.8 (C-14), 54.6 (C-9), 50.2 (C5), 45.6 (C-22), 44.2 (C-13), 42.7 (C-7), 40.9 (C-1), 39.3 (C-12), 36.7 (C-10), 31.5 (C-21), 31.0 (C-8), 27.0 (C-3), 24.4 (C-15), 22.8 (C-16), 21.8 (C-2), 20.7 (C-11), 20.6 (C-4), 15.5 (C-19), 13.5 (C-18); HRMS (ESI) calcd for $\mathrm{C}_{46} \mathrm{H}_{72} \mathrm{O}_{4} \mathrm{Na}(\mathrm{M}+\mathrm{Na})^{+}$: 711.5328, found: 711.5323 .

\subsubsection{3 $3,20 \beta$-Diacetyloxy-19-methylidene-5-pregnene (21)}

Prepared from $3 \beta, 20 \beta$-diacetyloxy-5-pregnen-19-al $500 \mathrm{mg}, 1.2 \mathrm{mmol}$ ) using the general Wittig methodology compound 21 was obtained as a white solid (338 mg, 78\%). Mp 87$88^{\circ} \mathrm{C}$; IR $\left(\mathrm{KBr}, \mathrm{cm}^{-1}\right)$ v 2936, 2905, 2869, 1729, 1370, 1241, 1033; ${ }^{1} \mathrm{H}$ NMR $\left(500 \mathrm{MHz}, \mathrm{CDCl}_{3}\right) \delta 5.65$ (dd, $\left.J=17.6,10.6 \mathrm{~Hz}, 1 \mathrm{H}, 19-\mathrm{H}\right), 5.63$ (dd, $J=5.1,1.9 \mathrm{~Hz}, 1 \mathrm{H}, 6-\mathrm{H}), 5.29$ (dd, $J=10.6,1.8 \mathrm{~Hz}, 1 \mathrm{H}, 22 \mathrm{~b}-\mathrm{H}$ ), 4.96 (dd, $J=17.5,1.8 \mathrm{~Hz}, 1 \mathrm{H}, 22 \mathrm{a}-\mathrm{H}), 4.83(\mathrm{~m}, 1 \mathrm{H}, 3-\mathrm{H}), 4.64(\mathrm{~m}, 1 \mathrm{H}, 20-\mathrm{H})$, $2.03\left(\mathrm{~s}, 3 \mathrm{H}\right.$, acetate), $2.02\left(\mathrm{~s}, 3 \mathrm{H}\right.$, acetate), $0.56(\mathrm{~s}, 3 \mathrm{H}, 18-\mathrm{H}) ;{ }^{13} \mathrm{C}$ NMR (125 MHz, $\left.\mathrm{CDCl}_{3}\right) \delta 170.6$ (COO), 170.4 (COO), 142.1 (C-22), 136.1 (C-5), 125.1 (C-6), 117.8 (C-19), 73.9 (C-3), 72.9 (C-20), 55.5 (C14), 54.9 (C-17), 50.2 (C-9), 44.7 (C-10), 42.2 (C-13), 39.2 (C-12), 38.4 (C-4), 35.6 (C-1), 31.7 (C-7), 31.0 (C-8), 28.3 (C-2), 25.4 (C-16), 24.3 (C-15), 21.5 ( $\left.\mathrm{CH}_{3} \mathrm{COO}\right), 21.4\left(\mathrm{CH}_{3} \mathrm{COO}\right), 21.2$ (C-11), 19.9 (C-21), 12.3 (C-18); MS (EI) $m / z 354(\mathrm{M}-\mathrm{AcO})^{+}, 294,161,117,91,79,55,43$. Anal. Calcd for $\mathrm{C}_{26} \mathrm{H}_{38} \mathrm{O}_{4}$ : C, 75.3; $\mathrm{H}, 9.2 \%$. Found: C, 75.5; $\mathrm{H}, 9.2 \%$.

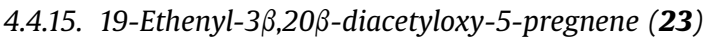

Prepared from 3 $\beta, 20 \beta$-diacetyloxy-5-pregnen-19-carboxyaldehyde (22, $40 \mathrm{mg}, 0.1 \mathrm{mmol}$ ) using the general Wittig methodology compound 23 was obtained as a white solid (30 mg, 76\%). Mp $125-127^{\circ} \mathrm{C}$; IR $\left(\mathrm{KBr}, \mathrm{cm}^{-1}\right) \nu 2956,2868,1740,1727,1370,1034,737$;
${ }^{1} \mathrm{H}$ NMR $\left(500 \mathrm{MHz}, \mathrm{CDCl}_{3}\right) \delta 5.76(\mathrm{ddt}, J=22.0,10.0,5.0 \mathrm{~Hz}, 1 \mathrm{H}, 22-$ $\mathrm{H}), 5.57(\mathrm{td}, J=5.2,1.8 \mathrm{~Hz}, 1 \mathrm{H}, 6-\mathrm{H}), 5.05$ (ddd, $J=17.2,2.1,1.5 \mathrm{~Hz}, 1 \mathrm{H}$ 23b-H), 4.96 (dt, $J=10.1,2.0 \mathrm{~Hz}, 1 \mathrm{H}, 23 \mathrm{a}-\mathrm{H}$ ), 4.83 (dq, $J=10.9,6.0 \mathrm{~Hz}$, $1 \mathrm{H}, 20-\mathrm{H}$ ), 4.63 (tt, $J=11.5,5.0 \mathrm{~Hz}, 1 \mathrm{H}, 3-\mathrm{H}$ ), 2.57 (ddt, $J=14.5,5.0$, $1.9 \mathrm{~Hz}, 1 \mathrm{H}, 19 \mathrm{a}-\mathrm{H}), 2.09$ (dd, $J=15.1,9.8 \mathrm{~Hz}, 1 \mathrm{H}, 19 \mathrm{~b}-\mathrm{H}), 2.04$ (s, 3H, acetate), 2.03 (s, 3H, acetate), 1.15 (d, $J=6.1 \mathrm{~Hz}, 3 \mathrm{H}, 21-\mathrm{H}), 0.62$ (s, $3 \mathrm{H}, 18-\mathrm{H}) ;{ }^{13} \mathrm{C}$ NMR $\left(125 \mathrm{MHz}, \mathrm{CDCl}_{3}\right) \delta 170.6$ (COO), 170.5 (COO), 137.3 (C-22), 136.8 (C-5), 124.7 (C-6), 115.3 (C-23), 73.9 (C-3), 72.9 (C-20), 57.2 (C-14), 54.8 (C-17), 51.4 (C-9), 42.4 (C-13), 39.7 (C-10), 39.5 (C-12), 38.2 (C-4), 37.2 (C-1), 36.5 (C-19), 32.5 (C-8), 31.4 (C-7), 27.7 (C-2), 25.4 (C-16), 24.2 (C-15), $21.6\left(\mathrm{CH}_{3} \mathrm{COO}\right), 21.4\left(\mathrm{CH}_{3} \mathrm{COO}\right)$, 21.2 (C-11), 19.9 (C-21), 12.7 (C-18); MS (EI) m/z 387 (M-allyl), 368 (M-AcOH), 327, 309, 267, 143, 133, 121, 105, 91, 79, 55, 43. Anal. Calcd for $\mathrm{C}_{27} \mathrm{H}_{40} \mathrm{O}_{4} \cdot 1 / 2 \mathrm{H}_{2} \mathrm{O}$ : C, $74.1 ; \mathrm{H}, 9.4 \%$. Found: C, $74.2 ; \mathrm{H}, 9.1 \%$.

\subsubsection{E-1,2-Bis-(3 $\beta, 20 \beta$-diacetoxy-5-pregnen-19-yl)-ethene (24)}

Prepared from $23(22 \mathrm{mg}, 0.05 \mathrm{mmol}$ ) following the general MW assisted metathesis methodology, after chromatography (silica gel, ethyl acetate/hexanes) compound $\mathbf{2 4}$ was obtained as a white solid (12.4 mg, 64\%). Mp 195-198 ${ }^{\circ} \mathrm{C} ; \mathrm{IR}\left(\mathrm{KBr}, \mathrm{cm}^{-1}\right) \nu 2939,2873,2850,1733$, $1367,1247,1031,926 ;{ }^{1} \mathrm{H}$ NMR $\left(500 \mathrm{MHz}, \mathrm{CDCl}_{3}\right) \delta 5.48(\mathrm{~d}, J=5.0 \mathrm{~Hz}, 1 \mathrm{H}$, 6-H), $5.40(\mathrm{~m}, 1 \mathrm{H}, 22-\mathrm{H}), 4.83(\mathrm{dq}, J=10.4,6.0 \mathrm{~Hz}, 1 \mathrm{H}, 20-\mathrm{H}), 4.62(\mathrm{tt}$, $J=11.7,5.0 \mathrm{~Hz}, 1 \mathrm{H}, 3-\mathrm{H}), 2.44$ (dd, $J=15.7 \mathrm{~Hz}, 5.2,1 \mathrm{H}, 19 \mathrm{a}-\mathrm{H}), 2.05$ (3H, s, acetate), $2.04(3 \mathrm{H}, \mathrm{s}$, acetate), $1.16(\mathrm{~d}, J=6.1 \mathrm{~Hz}, 3 \mathrm{H}, 21-\mathrm{H}), 0.65(3 \mathrm{H}, \mathrm{s}, 18-$ $\mathrm{H}) ;{ }^{13} \mathrm{C}$ NMR (125 MHz, CDCl 3 ) $\delta 170.6$ (COO), 170.5 (COO), 137.1 (C-5), 129.2 (C-22), 124.4 (C-6), 73.9 (C-3), 72.9 (C-20), 57.1 (C-14), 54.9 (C-17), 51.3 (C-9), 42.3 (C-13), 40.1 (C-10), 39.4(C-12), 38.4(C-4), 37.1 (C-1), 35.5 (C-19), 32.7 (C-8), $31.6(\mathrm{C}-7), 27.7$ (C-2), 25.6 (C-16), 24.2 (C-15), 21.5 (C$11), 21.5\left(\mathrm{CH}_{3} \mathrm{COO}\right), 21.5\left(\mathrm{CH}_{3} \mathrm{COO}\right), 19.9(\mathrm{C}-21), 12.7$ (C-18); $\mathrm{MS}$ (ESI) $\mathrm{m} / \mathrm{z}$ $387,327,267,143,121,58,43$. Anal. Calcd for $\mathrm{C}_{52} \mathrm{H}_{76} \mathrm{O}_{8}$ : C, $75.3 ; \mathrm{H}, 9.2 \%$. Found: C, 75.8; $\mathrm{H}, 9.5 \%$. Further elution rendered a fraction of unreacted 23 (3 mg, 14\%).

\section{Acknowledgements}

This work was supported by grants from Universidad de Buenos Aires, ANPCyT and CONICET (Argentina).

\section{Supplementary data}

Supplementary data includes ${ }^{1} \mathrm{H}$ and ${ }^{13} \mathrm{C}$ NMR spectra for all monomers and dimeric steroids with the complete $E / Z$ geometry analysis data of dimers by the ${ }^{1} \mathrm{H}$ NMR simulation-matching method. Supplementary data associated with this article can be found in the online version, at doi:10.1016/j.tet.2009.03.006.

\section{References and notes}

1. Clemons, P. A. Curr. Opin. Chem. Biol. 1999, 3, 112-115.

2. Diver, S. T.; Schreiber, S. L. J. Am. Chem. Soc. 1997, 119, 5106-5109.

3. Nicolaou, K. C.; Hughes, R.; Cho, S. Y.; Wissinger, N.; Smethurst, C.; Enderman, R. Angew. Chem., Int. Ed. 2000, 39, 3823-3828.

4. For reviews on dimeric steroids see: Nahar, L.; Turner, A. B. Curr. Med. Chem 2007, 14, 1349-1370 and Li, Y. X.; Dias, J. R. Chem. Rev. 1997, 97, 283-304.

5. (a) Mc Kenna, J.; Mc Kenna, J. M.; Thornthwaite, D. W. J. Chem. Soc., Chem. Commun. 1977, 809-811; (b) Hoffman, S.; Kumpf, W. Z. Chem. 1986, 8, 293-295.

6. López-Antón, N.; Rudy, A.; Barth, N.; Schmitz, L. M.; Pettit, G. R.; SchulzeOsthoff, K.: Dirsch, V. M.; Vollmar, A. M. J. Biol. Chem. 2006, 281, 33078-33086.

7. Opsenica, D.; Pocsfalvi, G.; Juramic, Z.; Tinant, B.; Declercq, J.-P.; Kyle, D. E.; Milhous, W. K.; Šolaja, B. A. J. Med. Chem. 2000, 43, 3274-3282.

8. Gouin, S.; Zhu, X. X. Langmuir 1998, 14, 4025-4029.

9. Harmatha, J.; Budesinsky, M.; Vokac, k. Steroids 2002, 67, 127-135.

10. Janout, V.; Jing, B. W.; Regent, S. L. Bioconjugate Chem. 2002, 13, 351-356. 11. Pandey, P. S.; Rai, R.; Singh, R. B. J. Chem. Soc., Perkin Trans. 1 2002, 918-923. 12. Guthrie, J. P.; Cossar, J.; Darson, B. A. Can. J. Chem. 1986, 64, 2456-2469.

13. Templeton, J. F.; Majgier-Baranowska, H.; Marat, K. Steroids 2000, 65, 219-223.

14. DellaGreca, M.; Iesce, M. R.; Previtera, L.; Tamussi, F.; Zarrelli, A. J. Org. Chem. 2002, 67, 9011-9015.

15. Morzycki, J. W.; Kalinowski, S.; Lotowski, Z.; Rabiczko, J. Tetrahedron 1997, 57, 10579-10590. 
16. Di Chenna, P. H.; Veleiro, A. S.; Sonego, J. M.; Ceballos, N. R.; Garland, M. T.; Baggio, R. F.; Burton, G. Org. Biomol. Chem. 2007, 5, 2453-2457.

17. Veleiro, A. S.; Taich, P. J.; Alvarez, L. D.; Di Chenna, P. H.; Burton, G. Tetrahedron Lett. 2005, 46, 4235-4238.

18. Grubbs, R. H. Tetrahedron 2004, 60, 7117-7140.

19. Bérubé, M.; Poirier, D. Org. Lett. 2004, 6, 3127-3130.

20. Rega, M.; Jiménez, C.; Rodríguez, J. Steroids 2007, 72, 729-735.

21. Chatterjee, A. K.; Choi, T.-L.; Sanders, D. P.; Grubbs, R. H. J. Am. Chem. Soc. 2003 $125,11360-11370$.

22. Bargiggia, F. C.; Murray, W. V. J. Org. Chem. 2005, 70, 9636-9639.
23. Concepción, J. I.; Francisco, C. G.; Freire, R.; Hernandez, R.; Salazar, J. A.; Suarez, E. J. Org. Chem. 1986, 51, 402-404.

24. Tochtrop, G. P.; DeKoster, G. T.; Cistola, D. P.; Covey, D. F. Bioorg. Med. Chem. 2002, 12, 433-435.

25. Fajkos, J.; Josca, J. Collect. Czech. Chem. Commun. 1979, 44, 251-258.

26. Joselevich, M.; Ghini, A. A.; Burton, G. Org. Biomol. Chem. 2003, 1, 939-943.

27. Dictionary of Steroids: Chemical Data, Structures and Bibliographies; Hill, R. A., Kirk, D. N., Makin, H. L., Murphy, G. M., Eds.; Chapman \& Hall: Cambridge, Great Britain, 1991.

28. Aburatani, N.; Takeuchi, T.; Mori, K. Synthesis 1987, 181-183. 